\title{
Herpes Genitalis pada Kehamilan
}

\author{
Dhara Alifa \\ Fakultas Kedokteran Universitas Kristen Maranatha \\ Korespondensi: Dhara Alifa, Email: dhara.alifa@gmail.com
}

\begin{abstract}
Abstrak
Herpes genitalis pada kehamilan merupakan infeksi pada genital disebabkan Herpes simplex virus (HSV) dengan gejala berupa vesikel berkelompok dengan dasar eritema dan bersifat rekurens pada perempuan hamil. HSV dibagi menjadi HSV-1 dan HSV-2. HSV-2 paling sering menyebabkan herpes genital sekitar $82 \%$ kasus ditularkan melalui kontak seksual, HSV-1 lebih sering menyebabkan herpes non-genital, tetapi terjadi peningkatan kasus herpes genitalis diakibatkan HSV-1 karena praktek seksual orogenital. Penelitian tahun 2000-2001 dilakukan pada sekitar 16.000 ibu hamil melaporkan 16\% terinfeksi HSV-2 dan 66\% terinfeksi HSV-1. Infeksi HSV dibagi menjadi infeksi primer, non-primer, rekurens, dan asimptomatis. Frekuensi infeksi HSV neonatus di Amerika Serikat adalah 1/12500 kelahiran hidup. Herpes genitalis pada kehamilan memungkinkan penularan ke janin pada masa intrauterine $5 \%$, perinatal $85 \%$, atau postnatal $10 \%$. Metode pewarnaan Giemsa, kultur HSV, biologi molekular (PCR), pemeriksaan histopatologi, atau serologi membantu menegakan diagnosis HSV. Penularan pada janin dapat menyebabkan abortus, stillbirth, pertumbuhan terhambat, kelainan kongenital, dan kematian. Penggunaan asiklovir atau valasiklovir pada ibu hamil sebagai terapi utama dan terapi supresif. Terapi supresif digunakan untuk mencegah, menurunkan frekuensi rekurensi, menurunkan penularan selama kehamilan, dan menurunkan angka pelaksanaan sectio caesaria. Infeksi herpes genitalis pada kehamilan diatas 34 minggu direncanakan sectio caesarea untuk mengurangi risiko transmisi virus ke bayi. Kontak lama neonatus dengan jalur persalinan pada saat melahirkan spontan akan meningkatkan risiko tertularnya neonatus oleh HSV.
\end{abstract}

Kata Kunci : Herpes Genital, Kehamilan, HSV, Sectio Cesarea, Terapi Supresif

\section{Genital Herpes in Pregnancy}

\begin{abstract}
Genital herpes in pregnancy is an genital infection caused by the Herpes simplex virus (HSV) with symptoms in the form of grouped vesicles on an erythematous basis and is recurrency cases in pregnant women. HSV has HSV1 and HSV-2. HSV-2 often cause genital herpes about $82 \%$ of cases and transmitted by sexual contact, HSV-1 caused more often non-genital herpes more often, but cases of genital herpes caused by HSV-1 were increasing due to orogenital sexual practices. A study in 2000-2001 conducted on about 16,000 pregnant women reported that $16 \%$ of cases were infected with HSV-2 and $66 \%$ were infected with HSV-1. HSV infection is divided into primary infection, non-primary, recurrent, and asymptomatic. The frequency of HSV-infected neonates in the United States is 1/12500 live of births. Genital herpes in pregnancy allows transmission to the fetus $5 \%$ during intrauterine, $85 \%$ during perinatal, or $10 \%$ during postnatal. Giemsa staining methods, cell culture, molecular biology (PCR), histopathological examination, or serology would be helpful on establishing the diagnosis of HSV. Transmission to the fetus may cause abortion, stillbirth, growth-retardation, congenital disorders, and death. The use of Acyclovir or Valacyclovir for pregnant women may be considered as primary therapy and suppressive therapy. Suppressive therapy is applied to pregnant women to prevent and reduce the frequency of recurrence, transmissions during pregnancy, and the rate of sectio caesaria. Genital herpes infection after 34-weeks-pregnancy is planned for caesarean section to reduce the risk of transmitting the virus to the baby. Prolonged contact of neonates with canal birth at spontaneous delivery will increase the risk of HSV transmission to neonates.
\end{abstract}

Key word: Genital Herpes, Pregnancy, HSV, Caesarean Section, Suppressive Therapy 


\section{Pendahuluan}

Herpes genital adalah infeksi pada genital yang disebabkan oleh Herpes simplex virus (HSV) dengan gejala khas berupa vesikel yang berkelompok dengan dasar eritema dan bersifat rekurens. ${ }^{1}$ Herpes genitalis pada kehamilan adalah infeksi HSV yang mengenai alat genital dan sekitarnya pada perempuan hamil. ${ }^{2}$ Infeksi Herpes simplex virus (HSV) merupakan salah satu virus penyebab infeksi menular seksual dan memiliki prevalensi tinggi di seluruh dunia, termasuk Indonesia. Prevalensi HSV 6\% pada populasi umum dan $14 \%$ pada wanita hamil. ${ }^{3}$ Herpes genitalis dapat terjadi pada kehamilan memungkinkan virus untuk menular pada janin. Hal ini perlu diperhatikan dengan serius karena infeksi atau reaktivasi. Sebagian besar perempuan tidak menyadari adanya infeksi HSV karena sering kali tidak menimbulkan gejala dan virus tersebut dapat masuk melalui

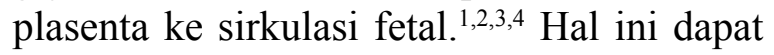
menyebabkan kerusakan atau kematian pada janin. Angka mortalitas janin yang terkena infeksi herpes genitalis ini mencapai $60 \%$, sebagian mengalami kelainan neurologis atau kecacatan pada mata. ${ }^{2,5}$ Frekuensi kelahiran neonatus dengan infeksi HSV di Amerika Serikat adalah 1/12.500 kelahiran hidup. ${ }^{6}$ Infeksi neonatal terdiagnosis sekitar 1.2001.500 kasus baru tiap tahunnya. ${ }^{5}$ Perkiraan infeksi HSV-2 pada orang-orang berusia 15-49 tahun sekitar 536.000.000 pada tahun 2003 atau sekitar $16 \%$ dari total populasi dunia, terbanyak pada perempuan. Infeksi pada neonatus sekitar 60/100.000 kelahiran hidup di dunia. ${ }^{7}$

\section{Herpes Simplex Virus}

Herpes simplex virus (HSV), atau Herpes virus hominis (HVH) merupakan tipe virus DNA double-stranded, berkapsid ikosahedral, ber-envelope, termasuk genus
Simplexvirus, subfamily Alphaherpesvirinae, dan famili Herpesviridae., ${ }^{2,3,6,8}$ Ukuran virus ini sekitar 150-200 nm. ${ }^{9}$ Virus ini memiliki masa inkubasi 1-26 hari, dengan rata-rata tujuh hari, setelah terjadi kontak langsung dengan lesi aktif, berlaku juga pada pasien tanpa gejala, dan replikasi virus terjadi di dalam nukleus sel hospes. ${ }^{2,9}$ Virus ini dibagi menjadi dua tipe, yaitu HSV-1 dan HSV-2. HSV-1 berhubungan dengan glikoprotein G1 dan HSV-2 berhubungan dengan glikoprotein G2. ${ }^{5}$ Kedua tipe virus ini sulit dibedakan secara serologik, biologik, maupun sifat fisikokimia. Kedua tipe HSV ini sensitif terhadap disinfektan dan pengaruh lingkungan. ${ }^{2,3,9}$

Infeksi HSV-1 maupun HSV-2 berhubungan dengan respon antibodi yang menyebabkan virus ini laten dalam saraf. ${ }^{10}$

HSV-2 merupakan tipe HSV yang paling sering menyebabkan herpes genital sekitar 82\% kasus dan ditularkan melalui kontak seksual, sedangkan HSV-1 lebih sering menyebabkan infeksi herpes nongenital dan biasanya didapat saat masih anakanak. ${ }^{2,4,6}$ Antibodi terhadap HSV-1 terdapat pada anak-anak sekitar $20 \%$, remaja $70 \%$, dan orang tua $97 \%$ dilaporkan penelitian seroepidemiologik. ${ }^{1,4,8}$ Antibodi HSV-2 terbentuk setelah melakukan hubungan seksual telah disimpulkan oleh WHO. Sekitar lima puluh juta dewasa muda dan dewasa telah terinfeksi HSV-2, ${ }^{2,3,4}$ Herpes genital akibat HSV-2 masih menjadi kasus terbanyak pada orang dewasa, tetapi terjadi peningkatan prevalensi herpes genitalis diakibatkan HSV-1 pada lebih dari setengah kasus baru pada dewasa muda karena kemungkinan adanya praktek seksual orogenital yang meningkat. ${ }^{4,6,8}$ Infeksi virus ini lebih tinggi sepuluh kali lipat pada perempuan penjaja seks. ${ }^{4}$ Herpes genital yang disebabkan HSV2 lebih sering terjadi rekurensi dibandingkan HSV-1. . $^{3,4,6}$

Penelitian pada tahun 2000 hingga 2001 yang dilakukan pada sekitar $16.000 \mathrm{ibu}$ hamil 
melaporkan sekitar 16\% terinfeksi HSV-2 dan $66 \%$ terinfeksi HSV-1. Risiko terinfeksi HSV-1 dan HSV-2 dapat terjadi sekitar 4-5\% selama kehamilan pada ibu hamil tanpa infeksi keduanya, sedangkan ibu hamil dengan HSV-1 dapat terinfeksi HSV-2 sekitar $2 \%$ Faktor-faktor yang dapat meningkatkan risiko penularan diantaranya jenis kelamin perempuan, durasi aktivitas seksual, etnis minor, infeksi genital terdahulu, status sosioekonomi, dan jumlah partner seksual. ${ }^{5}$

\section{Patofisiologi}

Infeksi HSV dibagi menjadi beberapa kategori episode, yaitu infeksi primer, infeksi non-primer, infeksi rekurens, dan pelepasan virus tanpa gejala (asymptomatic viral shedding). ${ }^{5}$ Episode infeksi primer, atau sering disebut infeksi inisial, merupakan fase virus memasuki tubuh hospesnya dengan adanya kontak secara fisik antara virus dan tempat yang sesuai, seperti membran mukosa atau kulit yang terluka lalu bereplikasi di epidermis dan dermis sehingga mengakibatkan destruksi sel dan inflamasi. ${ }^{1,5}$

Virus tersebut tidak perlu berasal dari genital. Gejala infeksi herpes genitalis akan timbul pada ibu hamil yang belum memiliki antibodi terhadap HSV setelah terpapar lesi herpes genitalis aktif pada pasangannya. ${ }^{4}$

Orang yang sudah terinfeksi dan menimbulkan gejala prodromal dimulai dengan rasa gatal, panas, kencang, atau kesemutan pada kulit sebelum timbulnya lesi pada kulit. ${ }^{6}$ Lesi kulit akan muncul sekitar 2-12 hari berupa papul, pustul, atau vesikel berkelompok dengan dasar eritema tergantung derajat beratnya penyakit., 2,,5,9

Lesi biasanya bertahan hingga dua puluh hari tanpa pemberian terapi. Respon antibodi akan terbentuk dan bertahan sepanjang hidup setelah 3-4 minggu sejak terinfeksi. ${ }^{5}$

Vesikel yang timbul mudah pecah dan dapat menimbulkan multipel erosi dan ulkus eritema dangkal setelah pecah. ${ }^{1,3,4}$ Gejala ini dapat hilang 2-3 minggu. Lokasi lesi yang sering timbul gejala pada perempuan adalah labia mayor, labia minor, klitoris, introitus, vagina, dan serviks, tapi lesi infeksi HSV ini dapat muncul juga di lipat paha, paha, dan bokong. ${ }^{1}$ Disuria dapat dirasakan jika lesi mengenai uretra atau parauretra. ${ }^{1}$ Gejala neuralgia, konstipasi, dan retention urin dapat muncul pada Herpetic Sacral Radiculomyelitis. ${ }^{6}$ Gejala bervariasi dari asimptomatik hingga berat, terutama gejala yang timbul mengenai serviks. HSV servisitis dapat disertai keluhan keputihan yang purulent dan darah. ${ }^{6}$ Kasus ini muncul pada $80 \%$ kasus infeksi primer HSV pada perempuan. ${ }^{1,5,11}$ Limfadenopati pada kelenjar limfe femoral dan inguinal dapat timbul akibat infeksi ini pada 75\% kasus. ${ }^{1,4,6}$ Gejalagejala lain perlahan dapat muncul mengikuti gejala awal seperti demam, sakit kepala, sakit otot, dan lemah badan., ${ }^{4,6}$ Ibu hamil dengan seronegatif HSV dapat menderita herpes genitalis pada saat persalinan karena memiliki pasangan dengan seropositif HSV2 terjadi sekitar 13\%, sekitar dua pertiga kasus terjadi secara asimptomatik, lesi yang timbul minimal, atau tidak spesifik sehingga tidak dapat dikenali oleh petugas medis. ${ }^{2}$ Kemudian, virus menginfeksi DNA hospes kemudian replikasi virus sehingga menimbulkan gejala. Perubahan hormonal pada ibu hamil meningkatkan risiko terjadinya infeksi dibandingkan diluar hamil. Antibodi spesifik belum terbentuk pada episode I infeksi primer, mengakibatkan lesi yang cukup luas dan berlangsung lama. ${ }^{1}$

Virus bermigrasi dari lesi mukokutan ke ganglion saraf regional melalui serabut saraf sensorik kemudian virus berdiam diri di ganglion dan bersifat laten sehingga tidak menimbulkan gejala.5 Seseorang yang memiliki riwayat infeksi HSV sebelumnya dapat terinfeksi lagi dengan tipe HSV yang lain.

Hasil pemeriksaan diagnostik menunjukan hasil pasien memiliki antibodi 


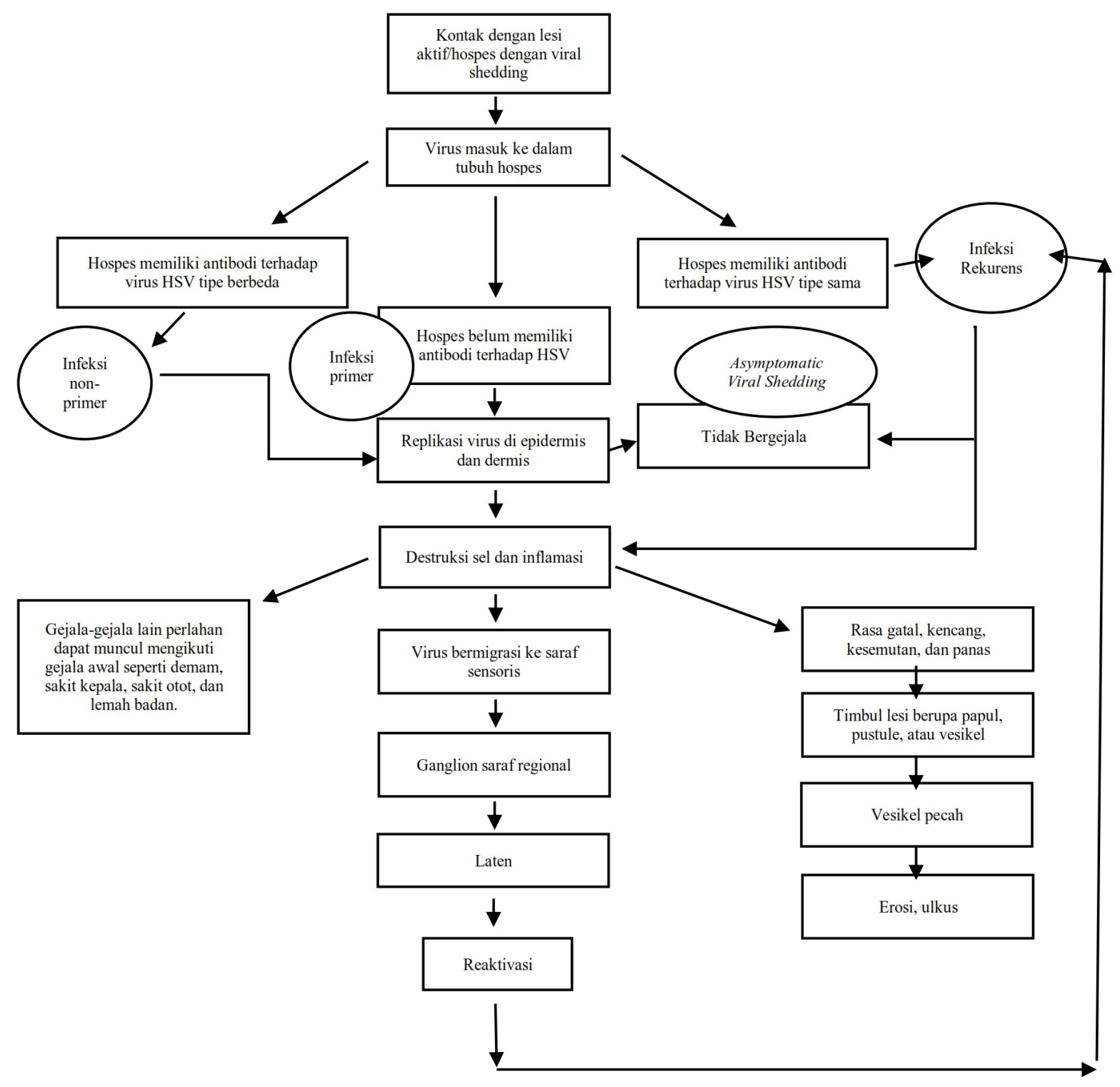

\section{Gambar 1 Patofisiologi infeksi HSV}

terhadap salah satu tipe HSV dan saat ini terinfeksi tipe HSV yang berbeda, hal ini disebut episode infeksi non-primer. Antibodi yang sudah dibentuk oleh tubuh dapat bereaksi silang terhadap virus HSV tipe berbeda sehingga gejala yang timbul tidak seberat episode inisial.4 Infeksi primer dengan non-primer dari gejala klinis sulit untuk dibedakan, hal ini memerlukan pemeriksaan serologi tipe spesifik untuk mengetahui adanya antibodi dari infeksi sebelumnya atau tidak. ${ }^{5}$

Beberapa faktor seperti faktor pencetus, pajanan HSV sebelumnya, episode terdahulu, dan tipe virus memengaruhi gejala yang timbul. ${ }^{4}$ Virus yang bersifat laten dapat mengalami reaktivasi dan melakukan replikasi kembali dengan atau tanpa gejala jika ada faktor pencetus, seperti trauma, koitus yang berlebihan, menstruasi, demam, gangguan pencernaan, stress, makanan, alkohol, obatobatan, atau factor pencetus lainnya, disebut infeksi rekurens. ${ }^{1,4}$ Sekitar 14\% kasus infeksi rekurens pada saat persalinan dari seluruh ibu hamil yang terinfeksi HSV dan hanya $3 \%$ diantaranya yang menularkan pada neonatus. ${ }^{5}$ Lesi rekurensi muncul di tempat infeksi primer terjadi dan antibodi spesifik 

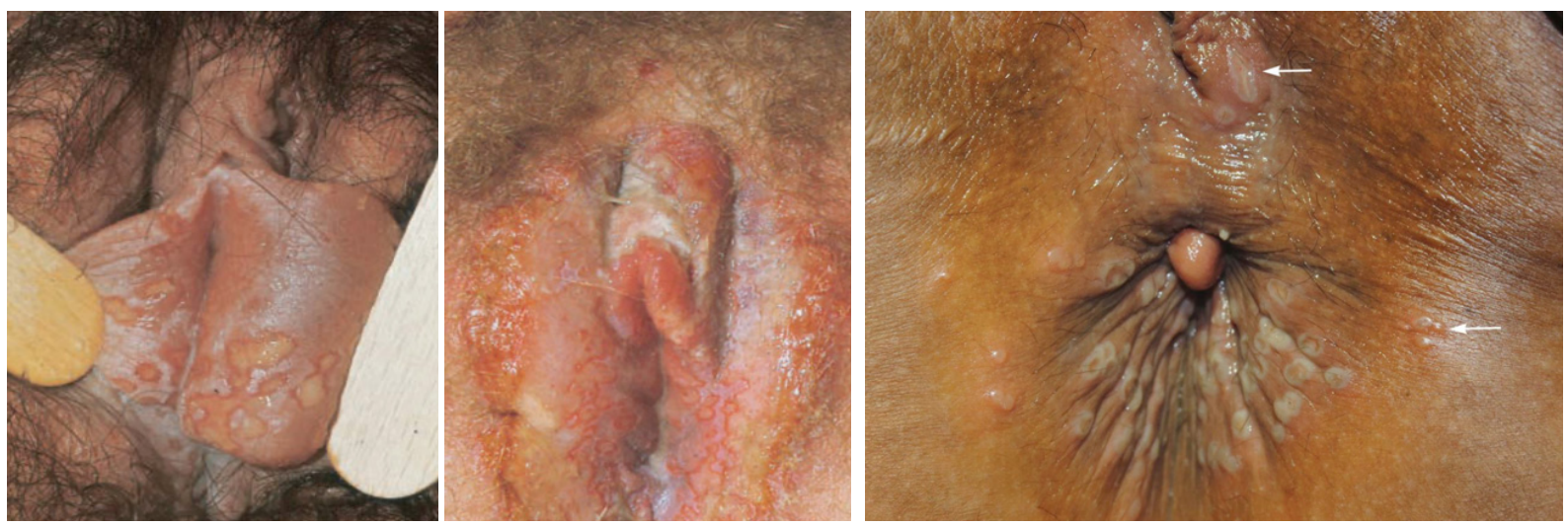

\section{Gambar 2 Lesi Aktif Herpes Genitalis ${ }^{4,6}$}

sudah terbentuk pada saat ini sehingga gejala yang timbul tidak seberat infeksi primer. ${ }^{1,3,4}$

Kemudian, paparan faktor pencetus pada kulit setempat menyebabkan kelemahan setempat dan menimbulkan lesi rekurens, selain virus yang terus menerus bermigrasi ke sel kulit. ${ }^{1,2}$ Rekurensi lebih sering terjadi pada infeksi yang diakibatkan HSV-2 enam belas kali lebih dibandingkan infeksi yang disebabkan HSV-1, selain itu frekuensinya pun lebih sering yaitu 3-4 kali per tahun. ${ }^{6}$

Rekurensi lebih sering terjadi pada satu tahun pertama sejak infeksi inisial dan akan berkurang seiring berjalannya waktu. $^{6}$ Reaktivasi virus sering kali tidak menimbulkan gejala, hanya sekitar $20 \%$ pasien dengan riwayat infeksi HSV mengeluhkan lesi di genital. ${ }^{10}$ Lesi yang timbul akan menghilang setelah sekitar 9 hari dan pelepasan virus terjadi selama sekitar 4 hari. Jumlah virus pada infeksi rekurens tidak sebanyak infeksi primer. ${ }^{5}$

Pelepasan virus tanpa gejala (asymptomatic viral shedding) dapat menyebabkan transmisi virus pada pasangan seksual yang belum terinfeksi dan janin setiap saat. Pelepasan virus dapat terjadi dalam waktu singkat sekitar 24-48 jam dari vulva, cervix, urethral, dan kulit perianal. Hal ini diketahui pelepasan virus tanpa gejala yang paling sering terjadi ada penularan infeksi HSV-2, terutama pada infeksi primer. ${ }^{4,10}$

Infeksi primer maupun rekurensi pada kehamilan dapat menyebabkan terjadinya kelainan pada janin, tetapi infeksi primer memiliki risiko lebih besar pada janin., ${ }^{2,4}$

Di Amerika dilaporkan terdapat infeksi neonatal terjadi pada 0,5-1/10.000 kelahiran dan sebagian besar ditularkan dari ibu yang tidak memiliki gejala infeksi HSV. ${ }^{4}$ Risiko penularan infeksi HSV pada janin atau neonatus berhubungan dengan lesi HSV aktif di genital, tipe HSV, penggunaan alat invasif pada persalinan, dan derajat penyakit ibu. ${ }^{4}$ Janin memiliki resiko terinfeksi pada masa intrauterine sekitar 5\%, perinatal sekitar $85 \%$, atau postnatal sekitar $10 \%$ selama neonatus kontak dengan virus yang hidup. ${ }^{4}$

Plasenta menjadi jalur transmisi pada masa intrauterin dari ibu ke janin dalam awal kehamilan (sekitar 20 minggu kehamilan) pada saat terjadi viremia. ${ }^{3}$ Infeksi saat intrapartum sangat berisiko menularkan pada janin karena terjadi transmisi melalui kontak secara langsung antara neonatus dengan jalan lahir ibu yang terinfeksi saat persalinan.

Kemungkinan penularan infeksi HSV pada bayi yang dilahirkan secara pervaginam pada saat ibu dalam masa infeksi primer dengan gejala, lebih berisiko mengalami infeksi neonatal sekitar 50-80\%. Risiko penularan pada neonatus dari ibu tergantung dari jenis infeksi yang terjadi, infeksi primer berisiko 50\%, infeksi non-primer 33\%, dan infeksi rekurens atau pelepasan virus tanpa gejala berisiko $0-4 \%$. Neonatus yang lahir 
dari ibu terinfeksi HSV tanpa gejala terinfeksi herpes saat persalinan pada $70 \%$ kasus. Infeksi yang terjadi dapat berisiko menyebabkan infeksi pada neonatus berupa lesi HSV yang terlokalisir pada kulit, mata dan atau mulut (SEM) sekitar 40\% kasus; encephalitis HSV sekitar 40\%, dan HSV diseminata berupa disfungsi organ berat sekitar $32 \%$, jika tidak ditangani dapat meningkatkan mortalitas mencapai $80 \%$.,4,6,9 Infeksi postnatal dapat terjadi penularannya melalui kontak antara neonatus dengan orang-orang disekitarnya yang menderita herpes orolabial, di sekitar kuku, ujung jari, atau tempat lain maupun melalui air susu ibu. ${ }^{2,8}$

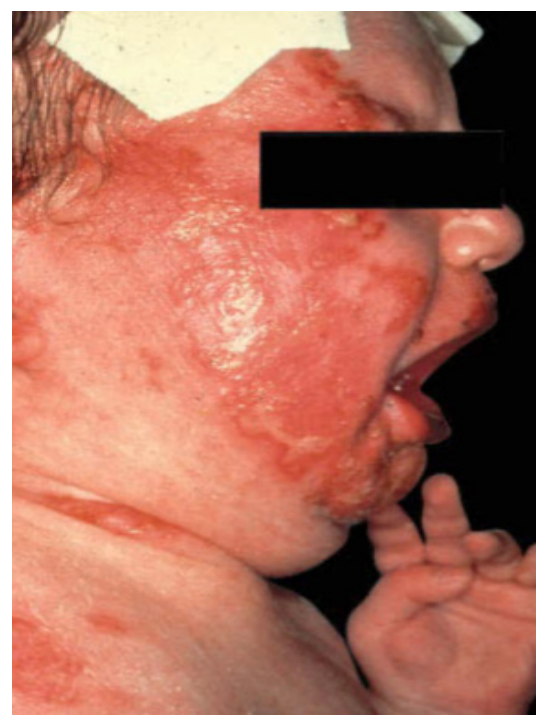

Gambar 3 Herpes Neonatal ${ }^{6}$

\section{Pemeriksaan Penunjang}

Perlu perhatian khusus pada ibu hamil yang terinfeksi HSV. ${ }^{1,4}$ Pemeriksaan rutin pada ibu hamil yang terinfeksi HSV tanpa gejala disarankan oleh beberapa organisasi kesehatan di dunia. Pemeriksaan dengan anamnesis dan pemeriksaan diagnostik pada masa antenatal awal dan pada akhir kehamilan sehingga dapat meminimalisasi risiko penularan pada janin. ${ }^{1,2}$ Gejala herpes genitalis sering dibandingkan dengan kelainan lain karena memiliki gejala yang serupa seperti ulkus mole, ulkus durum pada sifilis, atau ulkus pada penyakit Behcet. ${ }^{9}$ Pemeriksaan laboratorium diperlukan untuk membantu mendiagosis herpes genitalis pada pasienpasien dengan gejala klinis khas. Pemeriksaan dapat dilakukan dengan ter virologi atau tes serologi tipe spesifik. Tes virologi dapat mengambil sampel pemeriksaan dari apusan lesi mukokutan aktif, disarankan diambil dari dasar vesikel. ${ }^{4}$ Sampel diperiksa dengan tes Tzanck-Smear dengan pewarnaan Giemsa atau Wright dan ditemukan sel raksasa berinti banyak. Tes Tzanck-smear ini sederhana dan dapat dilakukan dengan alat sederhana, tetapi sensitivitas dan spesifitasnya rendah sehingga menyebabkan hasil false-positive atau false-negative. ${ }^{1,5}$ Pemeriksaan dengan metode ini sudah jarang digunakan dan hanya digunakan untuk keperluan sejarah. Kultur HSV dapat menjadi cara paling baik karena memiliki sensitivitas $70 \%$ dan spesifitas hampir $100 \%{ }^{5}$ Hasil positif didapatkan bila titer virus dalam spesimen tinggi, hasil ini dapat didapatkan dalam 24-48 jam. Granulasi sitoplasmik, degenerasi balon, dan adanya sel raksasa berinti banyak menunjukan adanya pertumbuhan virus. Pemeriksaan ini lebih sensitif terhadap HSV-2 dibandingkan HSV1. Spesimen dari perempuan yang terinfeksi HSV tanpa gejala dapat diambil dari serviks dan sekitarnya jika tidak terdapat lesi. Selain kultur jaringan, metode biologi molecular (polymerase chain reaction/PCR) dapat menjadi pilihan lain, metode ini lebih sensitif dibandingkan kultur jaringan. Namun dibalik sensitivitas dan spesifitas yang tinggi, cara ini memerlukan waktu yang lebih lama dan biaya yang dibutuhkan besar. ${ }^{2,9}$

Tes serologi dapat digunakan pada pasien dengan gejala genital rekuren, gejala atipikal dengan hasil kultur negatif, diagnosis klinis HSV tanpa konfirmasi, orang yang memiliki pasangan dengan HSV genital, dan dianjurkan dilakukan pada orang-orang dengan penyakit menular seksual. ${ }^{9}$

Tes ini dapat mendeteksi antibodi terhadap glikoprotein HSV secara spesifik 
dan membedakan infeksi primer dengan infeksi rekuren. Protein ini membangkitkan respon antibody tipe spesifik pada infeksi HSV-1 dan HSV-2., ${ }^{4,6}$ Antibodi IgG terbentuk setelah 1-2 minggu setelah infeksi primer dan menetap. Sensitivitas pemeriksaan ini 90$100 \%$ dengan spesifitas $99-100 \%{ }^{4}$ Skrining HSV pada ibu hamil dengan seronegative HSV, perlu dilakukan skrining pada pasangannya. Ibu hamil dengan seropositive atau seronegative HSV dengan pasangan seropositive, perlu dijelaskan mengenai transmisi HSV dan dianjurkan pemakaian kondom. Selain itu dijelaskan juga terjadinya rekurensi selama kehamilan perlu ditangani. ${ }^{2}$

\section{Penatalaksanaan Herpes Genitalis pada Kehamilan}

Penatalaksanaan yang dapat dilakukan untuk ibu hamil yang terinfeksi HSV perlu menentukan usia kehamilan saat terinfeksi. ${ }^{2}$ Pada infeksi primer, dapat dipertimbangkan penggunaan asiklovir atau valasiklovir pada ibu hamil secara oral atau intravena tergantung berat penyakitnya untuk terapi dan terapi supresif. asiklovir dapat menghambat replikasi virus HSV secara selektif dan tidak banyak mempengaruhi sel normal.

Asiklovir akan melintasi plasenta dan terkumpul di cairan amnion selama kehamilan. Konsentrasi obat ini dalam tubuh ibu sama dengan konsentrasi dalam tubuh janin. Valasiklovir mirip dengan asiklovir tetapi memiliki bioavailibilitas lebih tinggi karena zat tambahan. Kedua obat ini termasuk kategori B dan dapat digunakan selama kehamilan. ${ }^{5}$

Pemberian asiklovir oral dengan dosis $5 \times 200 \mathrm{mg}$ atau $3 \times 400 \mathrm{mg}$ dalam $7-10$ hari diberikan pada infeksi primer herpes genitalis atau asiklovir intravena dengan dosis $5-10 \mathrm{mg} /$ kgBB setiap 8 jam untuk 2-7 hari diberikan pada infeksi primer herpes genitalis dengan gejala berat pada kehamilan.,

Selain asiklovir, valasiklovir dengan dosis 2x1000 mg untuk 7-10 hari dapat diberikan pada infeksi primer. Infeksi rekurens dapat diberikan asiklovir dengan pilihan dosis $3 \times 400 \mathrm{mg}$ selama lima hari, $2 \times 800 \mathrm{mg}$ selama lima hari, atau dosis $3 \times 800$ mg selama dua hari. Sedangkan pemberian valasiklovir dapat diberikan dengan dosis $2 \times 500 \mathrm{mg}$ selama tiga hari atau $1 \times 1000$ mg selama lima hari. Penggunaan antivirus pada terapi untuk infeksi rekurensi dalam kehamilan digunakan sebagai pereda gejala., ${ }^{4,6}$

Terapi supresif dapat digunakan pada ibu hamil untuk mencegah, menurunkan frekuensi rekurensi, menurunkan angka penularan

Tabel 1 Dosis Obat Terapi HSV

\begin{tabular}{|c|c|c|c|}
\hline Kategori infeksi & Obat & Dosis & Lama pemberian \\
\hline \multirow[t]{3}{*}{ Infeksi Primer } & Asiklovir & $5 \times 200 \mathrm{mg}$ & 7-10 hari \\
\hline & & $3 \times 400 \mathrm{mg}$ & 7-10 hari \\
\hline & Valasiklovir & $2 \times 1000 \mathrm{mg}$ & 7-10 hari \\
\hline \multirow[t]{5}{*}{ Infeksi rekurens } & Asiklovir & $3 \times 400 \mathrm{mg}$ & 5 hari \\
\hline & & $2 \times 800 \mathrm{mg}$ & 5 hari \\
\hline & & $3 \times 800 \mathrm{mg}$ & 2 hari \\
\hline & Valasiklovir & $2 \times 500 \mathrm{mg}$ & 3 hari \\
\hline & & $1 \times 1000 \mathrm{mg}$ & 5 hari \\
\hline \multirow[t]{2}{*}{ Terapi supresif } & Asiklovir & $3 \times 400 \mathrm{mg}$ & $\begin{array}{l}\text { Sejak usia kehamilan } 36 \\
\text { minggu hingga persalinan }\end{array}$ \\
\hline & Valasiklovir & $2 \times 500 \mathrm{mg}$ & $\begin{array}{l}\text { Sejak usia kehamilan } 36 \\
\text { minggu hingga persalinan }\end{array}$ \\
\hline
\end{tabular}


selama kehamilan, dan menurunkan angka pelaksanaan sectio caesaria. Terapi supresif dapat menggunakan asiklovir dengan dosis $3 \times 400 \mathrm{mg}$ atau valasiklovir $2 \times 500 \mathrm{mg}$ sejak usia kehamilan 36 minggu hingga persalinan. Pemberian asiklovir dan valasiklovir belum terbukti mengakibatkan adanya gangguan pada janin dan dapat diberikan pada ibu menyusui karena konsentrasi obat di dalam air susu ibu kecil. ${ }^{2,4}$

Ibu hamil yang terinfeksi pada masa kehamilan trimester I dan II, segera diberikan asiklovir. Jika dapat dilakukan, perlu ditentukan apa penyebab infeksinya, HSV-1 atau HSV-2, dan menentukan apakah ini infeksi primer, gejala pertama non-primer, atau episode pertama infeksi rekurensi. ${ }^{2}$ Observasi terjadinya rekurensi selama kehamilan sampai usia kehamilan aterm, ibu hamil dapat melahirkan secara spontan dengan syarat tidak menggunakan alat-alat seperti forcep atau vacuum, pada saat melahirkan. Jika infeksi terjadi pada 6 minggu terakhir kehamilan, disarankan untuk melahirkan secara pembedahan atau section caesaria sebelum atau empat jam sesudah pecah ketuban. Kontak lama neonatus dengan sekret infeksius pada saat melahirkan spontan akan meningkatkan risiko tertularnya neonates oleh HSV. Sectio caesaria tidak rutin dilakukan, hanya dilakukan pada ibu hamil dengan viral shedding dan untuk ibu hamil dengan lesi aktif atau sedang mengalami gejala prodormal pada saat hampir/saat melahirkan. Ibu hamil dengan riwayat infeksi HSV tapi tidak timbul lesi aktif di genital pada saat persalinan atau memiliki lesi aktif di tempat selain genital tidak disarankan dilakukan section caesaria. ${ }^{2,4,9}$

Infeksi HSV yang terjadi pada usia kehamilan 30-34 minggu memerlukan pemeriksaan serologik untuk menentukan infeksi primer atau bukan. Jika didapatkan hasil sebagai infeksi primer, berikan terapi asiklovir tergantung berat ringannya penyakit, atau pemberian asiklovir supresi hingga waktu persalinan untuk menekan pelepasan virus. ${ }^{2,4}$ Timbulnya gejala atau tidak pada masa persalinan menentukan langkah selanjutnya. Sectio Caesaria segera dilakukan bila gejala timbul dan perlu penjelasan pada pasien dan keluarga mengenai semua risiko, sedangkan ibu hamil tanpa gejala pada masa persalinan boleh dilakukan persalinan pervaginam. ${ }^{2}$ Kedua cara tersebut tetap dibarengi pemberian asiklovir sebagai terapi supresi pada ibu. ${ }^{2,4}$ Setelah persalinan, dilakukan kultur virus dalam waktu 12-24 jam dan observasi neonatus. Neonatus yang mengalami gejala perlu diberikan terapi dengan asiklovir segera. ${ }^{2}$

Kehamilan di atas 34 minggu dengan infeksi herpes genitalis diberikan terapi asiklovir seperti pengobatan pada usia kehamilan 30-34 minggu, tetapi pada usia kehamilan ini segera direncanakan section caesarea untuk mengurangi risiko transmisi virus ke bayi. Setelah persalinan, dilakukan kultur virus dari bayi dalam waktu 12-24 jam dan observasi neonatus. Terapi asiklovir diberikan pada bayi atau diberikan setelah diobservasi dan timbul gejala. Pada kasus tertentu terjadi persalinan pervaginam saat persiapan, dilakukan kultur virus dari bayi dalam 12-24 jam dan pemberian asiklovir dapat dipertimbangkan. Jika hasil kultur virus dari bayi negative, hentikan pemberian terapi asiklovir. ${ }^{2}$ Pemberian ASI diperbolehkan selama tidak terdapat lesi aktif di payudara.

Perilaku bersih dan sehat dengan mencuci tangan perlu ditingkatkan. ${ }^{4}$ Infeksi primer yang cepat ditangani dapat menghasilkan prognosis yang lebih baik, sedangkan infeksi rekurens hanya bisa dibatasi frekuensi kekambuhannya. ${ }^{1}$

Ibu hamil dengan riwayat infeksi rekurensi, perlu ditandai dalam status dan menjadi perhatian. Melakukan pemeriksaan untuk mencari timbul atau tidaknya lesi pada masa awal persalinan. Pemberian asiklovir supresif pada 2-4 minggu di akhir kehamilan. Jika lesi tidak ditemukan, risiko neonatal 
rendah dan ibu hamil dapat melahirkan secara pervaginam. Saat bayi lahir perlu diobservasi secara ketat dan pemberian asiklovir dapat diberikan saat timbul gejala herpes neonatal.

Dibandingkan perempuan yang tidak hamil, Gejala infeksi HSV yang timbul lebih berat pada ibu hamil. ${ }^{2,3,4}$

Infeksi pada masa intrapartum penularan pada janin dapat menyebabkan abortus, stillbirth, pertumbuhan terhambat, kelainan perkembangan psikomotor, kelainan kulit (blister, scarring), atau kelainan kongenital berupa kelainan mata (chorioretinitis, microphtalmia, katarak), kelainan neurologis (kalsifikasi intrakranial, microcephali, hydraencephaly, encephalitis, meningitis) hingga kematian jika tidak diterapi dengan baik. ${ }^{1,2,4,6,9}$ Perlu perhatian khusus pada ibu hamil dengan kelainan ini. Hasil dari penatalaksanaan herpes genital sering kali tidak memuaskan, tapi penanganan yang baik dengan konseling, pemeriksaan diagnostik, penatalaksanaan antivirus, dan pencegahan timbulnya lesi aktif pada saat persalinan yang dilakukan dengan baik dan tepat dapat memperbaiki hasil pengobatan. ${ }^{8}$ Simpulan herpes genitalis pada kehamilan merupakan infeksi pada genital disebabkan Herpes simplex virus (HSV) dengan gejala berupa vesikel berkelompok dengan dasar eritema dan bersifat rekurens pada perempuan hamil. HSV dibagi menjadi HSV-1 dan HSV-2. HSV-2 paling sering menyebabkan herpes genital sedangkan HSV-1 lebih sering menyebabkan herpes non-genital, Infeksi HSV dibagi menjadi infeksi primer, nonprimer, rekurens, dan asimptomatis. Hal ini perlu diperhatikan dengan serius karena infeksi atau reaktivasi herpes genitalis pada kehamilan memungkinkan penularan ke janin pada masa intrauterine $5 \%$, perinatal $85 \%$, atau postnatal $10 \%$. Penularan pada janin dapat menyebabkan abortus, stillbirth, pertumbuhan terhambat, kelainan kongenital, dan kematian. Penggunaan asiklovir atau valasiklovir pada ibu hamil sebagai terapi utama maupun terapi supresif. Terapi supresif digunakan untuk mencegah, menurunkan frekuensi rekurensi, menurunkan penularan selama kehamilan, dan menurunkan angka pelaksanaan sectio caesaria.

\section{Daftar Pustaka}

1. Daili, Sjaiful Fahmi, Hanny Nilasari, Wresti Indriatmi B. Makes, Farida Zubier, Rasmia Romawi, and Satiti Retno Pudjiati, . 2017. Infeksi Menular Seksual. Jakarta: Badan Penerbit Fakultas Kedokteran Universitas Indonesia.

2. Daili, Sjaiful Fahmi, and Wresti Indriatmi B. Makes, . 2002. Infeksi Virus Herpes. Jakarta: Balai Penerbit FK UI.

3. Djojosugito, Fauzia Andrini. 2016. "Infeksi Herpes Simpleks Dalam Kehamilan." Jurnal Ilmu Kedokteran (Fakultas Kedokteran Universitas Riau) 10 (1): 1-4.

4. Cunningham, F. Gary, Kenneth J. Leveno, Steven L. Bloom, Jodi S. Dashe, Barbara L. Hoffman, Brian M. Casey, and Catherine Y. Spong. 2018. Williams Obstetric 25th Edition. McGraw-Hill Education.

5. Grove, Marie K., and Nan G. O'Connell. 2020. MedScape. October 15. Accessed August 27, 2021. https://emedicine. medscape.com/article/274874-overview.

6. Kang, Sewon, Masayuki Amagai, Anna L. Bruckner, Alexander H. Enk, David J. Margolis, Amy J. McMichael, and Jeffrey S. Orringer, . 2019. Fitzpatrick's Dermatology 9th Edition. Vol. 2. 2 vols. McGraw-Hill Education.

7. Studahl, Marie, Paola Cinque, and Tomas Bergstrom, . 2018. Herpes Simplex Viruses. Boca Raton: CRC Press.

8. Singh, Sunit K., ed. 2019. Diagnostics to Pathogenomics of Sexually Transmitted Infections. Pondicherry: Wiley Blackwell

9. Passos, Mauro Romero Leal, Gutemberg Leão De Almeida Filho, Ivo Castelo 
Branco Coêlho, Luiz Carlos Moreira, Edilbert Pellegrini Nahn Junior, and José Eleutério Junior, . 2018. Atlas of Sexually Transmitted Diseases : Clinical Aspects and Differential Diagnosis. Rio de Janeiro: Springer.

10. Stanberry, Lawrence R., and Susan L. Rosenthal. 2013. Sexually Transmitted Disease : Vaccine, Prevention, and Control Second Edition. Elsevier.

11. Wolff, Klaus, Richard Allen Johnson, and Dick Suurmond. 2005. Fitzpatrick's Color Atlas \& Synopsis of Clinical Dermatology 5th Edition. McGraw-Hill Medical Publishing Division. 